\title{
Ecosystem vulnerability to alien and invasive species: a case study on marine habitats along the Italian coast
}

\author{
GIUSEPPE CORRIERO ${ }^{\mathrm{a}}$, CATALDO PIERRI ${ }^{\mathrm{a}, *}$, STEFANO ACCORONI $^{\mathrm{k}}$, GIORGIO ALABISO ${ }^{\mathrm{e}}$, \\ GIORGIO BAVESTRELLO ${ }^{\mathrm{d}}$, ENRICO BARBONE $^{\mathrm{c}}$, MAURO BASTIANINI ${ }^{\mathrm{f}}$, ANNA MARIA BAZZONI ${ }^{\mathrm{h}}$, \\ FABRIZIO BERNARDI AUBRY ${ }^{\mathrm{f}}$, FERDINANDO BOERO ${ }^{\mathrm{b}}$, MARIA CRISTINA BUIA ${ }^{\mathrm{g}}$, MARINA CABRINI', \\ ELISA CAMATTI ${ }^{\mathrm{f}}$, FRINE CARDONE ${ }^{\mathrm{a}}$, BRUNO CATALETTO ${ }^{\mathrm{i}}$, RICCARDO CATTANEO VIETTI ${ }^{\mathrm{d}}$, ESTER CECERE $^{\mathrm{e}}$, \\ TAMARA CIBIC ${ }^{\mathrm{i}}$, PAOLO COLANGELO ${ }^{1}$, ALESSANDRA DE OLAZABAL ${ }^{\mathrm{i}}$, GIANFRANCO D'ONGHIA ${ }^{\mathrm{a}}$, \\ STEFANIA FINOTTO ${ }^{\mathrm{f}}$, NICOLA FIORE ${ }^{\mathrm{b}}$, DANIELA FORNASARO ${ }^{\mathrm{i}}$, SIMONETTA FRASCHETTI ${ }^{\mathrm{b}}$, \\ MARIA CRISTINA GAMBI ${ }^{\mathrm{g}}$, ADRIANA GIANGRANDE ${ }^{\mathrm{b}}$, CINZIA GRAVILI ${ }^{\mathrm{b}}$, ROSANNA GUGLIELMO ${ }^{\mathrm{g}}$, \\ CATERINA LONGO ${ }^{\mathrm{a}}$, MAURIZIO LORENTI ${ }^{\mathrm{g}}$, ANTONELLA LUGLIË ${ }^{\mathrm{h}}$, PORZIA MAIORANO ${ }^{\mathrm{a}}$, \\ MARIA GRAZIA MAZZOCCHI ${ }^{\mathrm{g}}$, MARIA MERCURIO ${ }^{\mathrm{a}}$, FRANCESCO MASTROTOTARO ${ }^{\mathrm{a}}$, MICHELE MISTRI ${ }^{\mathrm{j}}$, \\ MARINA MONTI ${ }^{\mathrm{i}}$, CRISTINA MUNARI $\mathrm{I}^{\mathrm{j}}$, LUIGI MUSCO ${ }^{\mathrm{m}}$, CARLOTTA NONNIS-MARZANO $^{\mathrm{a}}$, \\ BACHISIO MARIO PADEDDA ${ }^{\mathrm{h}}$, FRANCESCO PAOLO PATTI ${ }^{\mathrm{g}}$, ANTONELLA PETROCELLI ${ }^{\mathrm{e}}$, STEFANO PIRAINO ${ }^{\mathrm{b}}$, \\ GIUSEPPE PORTACCI ${ }^{\mathrm{e}}$, ALESSANDRA PUGNETTI ${ }^{\mathrm{f}}$, SILVIA PULINA $^{\mathrm{h}}$, TIZIANA ROMAGNOLI ${ }^{\mathrm{k}}$, ILARIA ROSATI ${ }^{\mathrm{b}}$, \\ DIANA SARNO ${ }^{\mathrm{g}}$, CECILIA TEODORA SATTA $^{\mathrm{h}}$, NICOLA SECHI $^{\mathrm{h}}$, STEFANO SCHIAPARELLI ${ }^{\mathrm{d}}$, BEATRICE SCIPIONE ${ }^{\mathrm{g}}$, \\ LETIZIA SION ${ }^{\mathrm{a}}$, ANTONIO TERLIZZI ${ }^{\mathrm{b}}$, VALENTINA TIRELLI ${ }^{\mathrm{i}}$, CECILIA TOTTI $^{\mathrm{k}}$, ANGELO TURSI ${ }^{\mathrm{a}}$, \\ NICOLA UNGARO' ${ }^{\mathrm{c}}$, ADRIANA ZINGONE ${ }^{\mathrm{g}}$, VALERIO ZUPO ${ }^{\mathrm{g}}$ and ALBERTO BASSET ${ }^{\mathrm{b}}$ \\ a Department of Biology, University of Bari 'Aldo Moro', Bari, Italy \\ ${ }^{\mathrm{b}}$ Department of Biological and Environmental Science and Technology, University of Salento, Lecce, Italy \\ ${ }^{\mathrm{c}}$ Apulian Regional Agency for the Environmental Prevention and Protection, Bari, Italy \\ ${ }^{\mathrm{d}}$ Department of Earth, Environment and Life Science, University of Genova, Genova, Italy \\ ${ }^{\mathrm{e}}$ National Research Council, Institute for Marine Coastal Environment, Taranto, Italy \\ ${ }_{\mathrm{f}}^{\mathrm{f}}$ National Research Council, Institute of Marine Science, Venezia, Italy \\ ${ }^{\mathrm{g}}$ Zoological Station Anton Dohrn, Napoli, Italy \\ ${ }^{\mathrm{h}}$ Department of Architecture, Urban Planning and Design, University of Sassari, Sassari, Italy \\ ${ }^{\mathrm{i}}$ National Institute of Oceanography and Experimental Geophysics, Trieste, Italy \\ ${ }^{\mathrm{j}}$ Department of Life Science and Biotechnology, Ferrara, Italy \\ ${ }^{\mathrm{k}}$ Department of Life and Environment Sciences, Polytechnic University of Marche, Ancona, Italy \\ ${ }^{1}$ National Research Council, Institute of Ecosystem Study, Verbania-Pallanza, Italy \\ ${ }^{\mathrm{m}}$ National Research Council, Institute for Marine Coastal Environment, Castellammare del Golfo, (TP), Italy
}

\begin{abstract}
1. Spread of alien species (AS) is a serious threat to marine habitats and analysis of principal descriptors of their occurrence is pivotal to set reliable conservation strategies.

2. In order to assess the susceptibility of marine habitats to biological invasions, a dataset was gathered of the occurrence of 3899 species from 29 phyla, taken from 93 marine sites located along the Italian coast in the period 2000-2012.
\end{abstract}

\footnotetext{
*Correspondence to: C. Pierri, Department of Biology, University of Bari ‘Aldo Moro', Bari, Italy. E-mail: cataldo.pierri@uniba.it
} 
3. In total, 61 AS belonging to 11 phyla have been recorded. Invertebrates were the most represented (63\%). Alien species were found in all the habitats examined (EUNIS, level 2), although they showed highest abundance in benthic habitats. Most of the AS were associated with a single EUNIS habitat, while some of them were present in more than one habitat. Trans-habitat occurrence suggests the potential invasiveness of AS.

4. According to statistical analysis, AS recorded could have been more numerous, since some of the marine habitats seemed to be still unsaturated. The model that best describes the spread of AS takes account of both native species richness $(\mathrm{Rn})$ and EUNIS habitat type as explanatory variables. The number of observed AS was directly related to $\mathrm{Rn}$ and it was highest in rocky circalittoral and infralittoral habitats.

5. The results of this macro-ecological study focus on the importance of performing large-scale studies, since adopting ecosystem approaches to marine invasion management seems especially fruitful.

6. The results, moreover, highlight the importance of AS monitoring of different habitats, from those subjected to anthropogenic pressure, historically considered to be hubs of introduction of AS, to the most biologically rich and diverse marine habitats. Indeed, it is necessary to set monitoring strategies to detect the introduction, the distribution and persistence of AS over time. These recommendations are especially significant in the light of the strategic plans currently under formulation in Mediterranean countries with regard to AS monitoring.

Copyright (C) 2015 John Wiley \& Sons, Ltd.

Received 19 May 2014; Revised 17 November 2014; Accepted 16 December 2014

KEY WORDS: marine alien species; Mediterranean EUNIS habitats; habitat vulnerability; invasive alien species; invasion

\section{INTRODUCTION}

The presence of alien species (AS) in areas where they have never been found previously is generating major concern in the international scientific community (Ricciardi and MacIsaac, 2008; Simberloff, 2014). The rate of aquatic AS introduction and the spread of invasive alien species (IAS) have increased rapidly in recent years, to the extent that these species are now considered to be one of the top five anthropogenic threats throughout the ocean (Nellemann et al., 2008; Costello et al., 2010; Coll et al., 2012). Invasive alien species adversely affect the stability of receiving ecosystems, leading to significant socio-economic costs and hazards for human health (Carlton, 1985; Lodge, 1993; IUCN, 2000; Mack et al., 2000; Streftaris and Zenetos, 2006; Galil, 2007; Kettunen et al., 2009). Discovering what makes ecosystems susceptible to biological invasion (Holdgate, 1986; Li et al., 2000) is one of the most important goals in invasion ecology. Thus, the ability to predict habitat invasibility, as an expression of the ecosystem's vulnerability to invasions, and to interpret the responses to bioinvasions is crucial for the implementation of ecosystem conservation tools (Hayes and Barry, 2008).

Ecosystem functioning is related to the strict relationships between their biotic and abiotic components, and biological invasions can alter the equilibrium among these components, thus affecting the integrity of natural environments worldwide (Hulme, 2007; Vilà et al., 2010). Nilsson and Grelsson (1995) defined fragility as the inverse of stability, relating these two ecosystem characteristics to the degree of change in species abundance and composition following human disturbance. Habitat fragility results from the multiple interactions of climatic, edaphic and biotic factors (Lonsdale, 1999; Davis et al., 2000) that shape the temporal and spatial heterogeneity of habitats and their biological communities. Climate variations, nutrient availability, and external disturbances, contribute to influencing interspecific interactions (facilitation, competition, and predation), their strength, and niche availability (Elton, 1958; Herbold and Moyle, 1986; Moyle and Light, 1996; Mack et al., 2000; Rejmanek, 2000; With, 2004; Paavola et al., 2005; Romanuk and Kolasa, 2005). 
However, successful invasions are relatively rare (Williamson and Fitter, 1996) and depend mainly on the interaction between invasiveness (i.e. the biologically related property of species to become established, spread to, or abundant in new communities) and invasibility (i.e. the susceptibility of habitats to the establishment or proliferation of invaders) (Colautti et al., 2006). Most AS do not find optimal environmental conditions for reproduction, persistence, or survival, and are kept under control by unfavourable physical and chemical variables or by biotic interactions within the native community. Habitat heterogeneity, community complexity, species-habitat interactions, biological traits (e.g. fecundity, propagule pressure, population growth rate), and the stochastic nature of environmental phenomena, are likely to play a key role in determining the invasion success of AS (Elton, 1958; Mack et al., 2000; Colautti et al., 2006; Hayes and Barry, 2008). According to Zaiko et al. (2007) the generalized model of an 'invader friendly' habitat could be defined by the following features: (i) the habitat has favourable physical conditions for maintaining diverse communities, and thereafter high native species richness might be considered as an indicator of a habitat's invasibility; (ii) the habitat lacks certain species which should be present under normal conditions; (iii) the habitat is disturbed by natural or human factors; and (iv) ecosystem properties are altered by previous introductions, creating unstable conditions (successfully established habitat engineering species should be considered as a powerful facilitative factor for further invasions).

While some communities are prone to bioinvasions, others are naturally resistant (Elton, 1958; Tilman, 1997; Stachowicz and Whitlatch, 1999; Levine, 2000). The 'biotic resistance hypothesis' (Elton, 1958; Rejmanek, 1989, Chapin et al., 1998; Levine et al., 2004) is based on the consideration that more diverse communities are very competitive and have an inherent ability to resist invasions. Conversely, communities with a small number of species offer a greater opportunity to access resources using different food webs and life strategies (trophic niches). In contrast, the 'biodiversity increasing invasibility hypothesis' describes highly diverse communities as being more subject to invasions because of the facilitative effect of both native richness and previously introduced species (Cohen and Carlton, 1998; Stohlgren et al., 2003). The hypothesis emphasizes positive rather than antagonistic interactions among species (Ricciardi, 2001): AS-AS facilitation has been widely recognized in terrestrial environments (Simberloff and von Holle, 1999; Richardson et al., 2000), and facilitation by natives could be equally common (Maron and Connors, 1996). These two hypotheses do not necessarily need to be mutually exclusive and certain invasive phenomena may thus be the effect and not the cause of ecological changes (Boero, 2002; Galil, 2007).

In Europe, all coastal waters are inhabited by AS. Some habitats, such as lagoons and ports, act as 'hubs' of introduction, and some regions have a larger array of AS (Paavola et al., 2005; Lotze et al., 2006; Zaiko et al., 2011). The Mediterranean Sea is one of the most important marine AS hotspots in the world (Occhipinti-Ambrogi, 2000; Quignard and Tomasini, 2000) in terms both of the number of species (Costello et al., 2010) and rate of introduction (Zenetos, 2010). To date 986 AS have been described (Zenetos et al., 2010, 2012) with an increasing trend due to shipping, aquaculture trade, and migration through the Suez Canal (Zenetos et al., 2010; Occhipinti-Ambrogi et al., 2011b; Katsanevakis et al., 2013). The Italian Peninsula is a biogeographical crossroads of the Mediterranean between the western and eastern basins, hosting 164 marine and brackish AS along its long coastline (Occhipinti-Ambrogi et al., 2011a, b). Among the most well-known marine biological invaders in the Mediterranean are the filamentous red alga Womersleyella setacea and the green alga Caulerpa cylindracea, two harmful invasive species (Athanasiadis, 1997; Boudouresque and Verlaque, 2002; Verlaque et al., 2005; Streftaris and Zenetos, 2006) currently spreading along the Italian coasts as well (Piazzi et al., 2005). These IAS can inhabit a wide range of subtidal hard and soft substrata from 0 to $70 \mathrm{~m}$ depth, thus altering the structure of native assemblages. Such species 
are deemed to alter the structure of the communities of hard substratum leading to a change in the species composition of associated fauna, thus threatening the conservation status of several marine communities in the Mediterranean (Argyrou et al., 1999; Gravez et al., 2001; Zenetos et al., 2005; Baldacconi and Corriero, 2009; de Caralt and Cebrian, 2013).

By combining the most complete dataset on the species inhabiting EUNIS (European Nature Information System, http://eunis.eea.europa.eu/) Mediterranean habitats, the aim of this work was to document the spread of AS in different marine habitats along the Italian coasts, showing the potential susceptibility of these habitats to biological invasions. Since the success of an invasion could be the result of a combination of different biological, ecological and environmental factors, the richness of AS was evaluated as a function of different predictors (native species richness, habitat differences, and geography). Several models identifying the variables that best explain the observed pattern of AS were realized in order to assess the impact of different predictors on the presence-absence of AS. In addition, the pattern of presence-absence of AS in different habitats was explicitly explored in order to assess habitat preferences (i.e. single or multiple habitats) of different species.

The EUNIS habitat classification is a comprehensive pan-European system to facilitate the harmonized description and collection of data across Europe through the use of criteria for habitat identification. Thus, there are two advantages of using the EUNIS classification: first, its use of widely accepted habitat types recognized by the scientific community, and second, it is a reference for the development of indicators and environmental reporting at both administrative and political levels.

The present paper represents the first comprehensive effort to analyse the distribution of AS along the Italian coast in marine ecosystem/habitat types considered in EUNIS, and thus it is an important step in setting conservation priorities, providing further insights of patterns of invasion across this area of the Mediterranean Sea.

\section{MATERIAL AND METHODS}

\section{Data collection, geographical and temporal scales of the datasets}

Taxonomic records were gathered from specific datasets belonging to several research institutions, both public and private. These data were shared within the context of the Alien Species Showcase (http://www.lifewatch.eu/web/ alien-species-showcase/virtual-lab) created within the framework of LifeWatch, the European e-science infrastructure offering ecological informatics services and tools to scientists and other public and private institutions involved in biodiversity and ecosystem research (Basset and Los, 2012).

The resulting dataset gathers biological diversity records from marine sites along the Italian coastline, subsequently merged into geographic macro areas (GMAs) as suggested by OcchipintiAmbrogi et al. (2011a). Some of the sites belong to the LTER-Italy network (Long Term Ecological Research Italian network, http://www. Iteritalia.it).

Overall, 12521 records (5067 planktonic, 7105 benthic, and 349 nektonic) from 93 marine sites have been gathered by the LifeWatch community in Italy. Marine sites included habitats classified as littoral rock and other hard substrata (two sites, EUNIS code level 2: A1), littoral sediment (three sites, EUNIS code level 2: A2), infralittoral rock and other hard substrata (eight sites, EuNIS code level 2: A3), circalittoral rock and other hard substrata (26 sites, EUNIS code level 2: A4), sublittoral sediment (eight sites, EUNIS code level 2: A5), deep-sea bed (two sites, EUNIS code level 2: A6), and pelagic water column (44 sites, EUNIS code level 2: A7). No lagoon or estuarial environments have been included in the present study. Each research unit provided lists of species generated from field research programmes on the biodiversity of specific habitats of reference. A nomenclatural revision of the dataset was carried out based on the taxonomic information provided by WoRMS (World Register of Marine Species, Boxshall et al., 2014). All data were screened for 
taxonomic reliability, synonymy and for the definition of 'alien' by taxonomy experts in the LifeWatch-Italy network. The dataset included data referred to the period 2000-2012.

The definition of AS adopted in this study refers to the deliberate or inadvertent introduction of living organisms (species, subspecies or lower taxa, gametes or propagules) owing to human activities (IUCN, 2000; Hulme, 2009). According to Olenin et al. (2010), natural changes in areal distribution do not define AS per se.

In operational terms and taking into account the history of species introduction, it is also useful to establish temporal benchmarks beyond which records of new species should be considered as part of the native biota. These benchmarks conventionally refer to events that have broken down natural barriers or have created new connections.

In this study, in accordance with Zenetos et al. (2010), the realization of the Suez Canal has been chosen as a benchmark for the Italian coasts. It represents a useful and convenient reference to indicate a period of great change in the Mediterranean, when the basin was put in communication with the Indo-Pacific flora and fauna, though it cannot be formally proved as the start of biological invasions.

\section{Statistical analysis}

To evaluate the richness of AS in relation to sampling efforts in different habitats, rarefaction curves for the whole dataset and for the two most represented EUNIS taxonomical groups in the LifeWatch dataset (algae and invertebrates) were obtained using the function rare curve implemented in the $\mathrm{R}$ ( $\mathrm{R}$ Core Team, 2014) package Vegan (Oksanen et al., 2013).

In order to model the AS richness, different generalized linear mixed models (GLMMs) were built by using three different potential predictor variables: native species richness $(\mathrm{Rn})$, habitat (according to EUNIS level 2 classification) and geographical location (GMA). GLMMs offer a flexible approach to model the sources of variation and correlation that arise from grouped data by combining the properties of linear mixed models, which incorporate random effects, and generalized linear models, which handle non-normal data (Bolker et al., 2009).

In this work, models were fitted using the AD Model Builder implemented in the glmmADMB package (Fournier et al., 2012) in the R statistical environment. The AD Model Builder fits models using a GLMM that takes into account an excess of zeros in the raw data (the norm in the presence

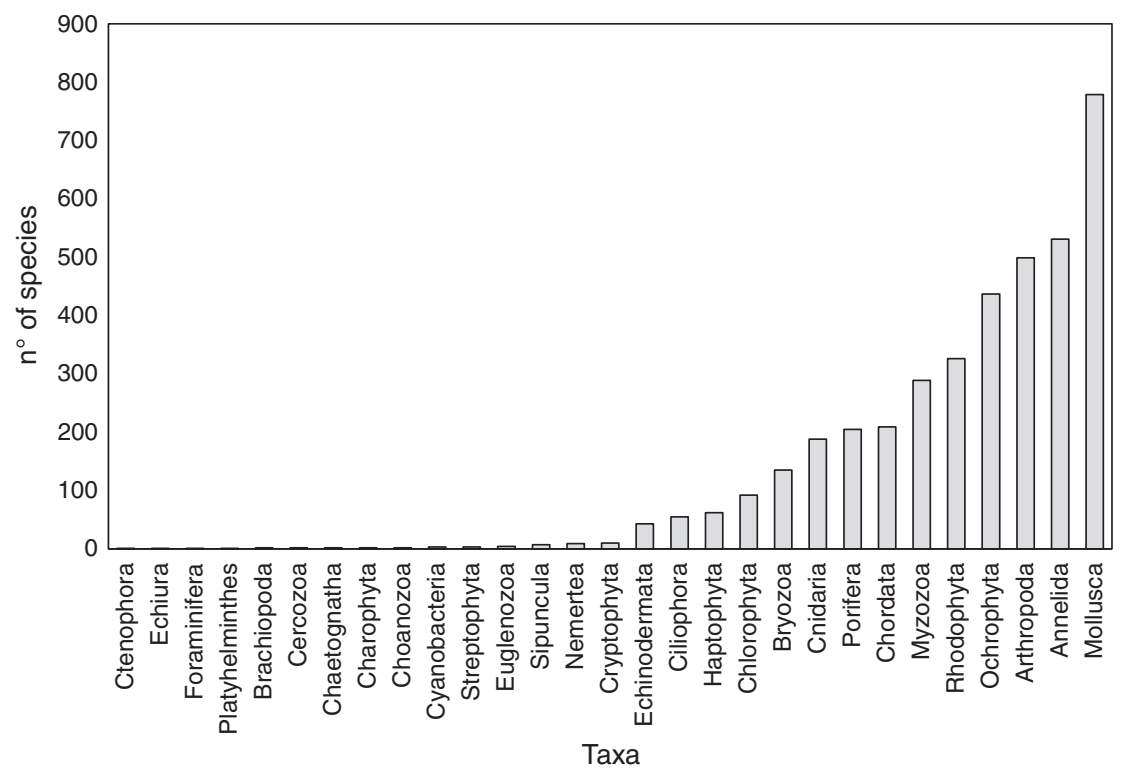

Figure 1. Distribution of total recorded species among taxonomic groups. 
Table 1. List of the recorded AS

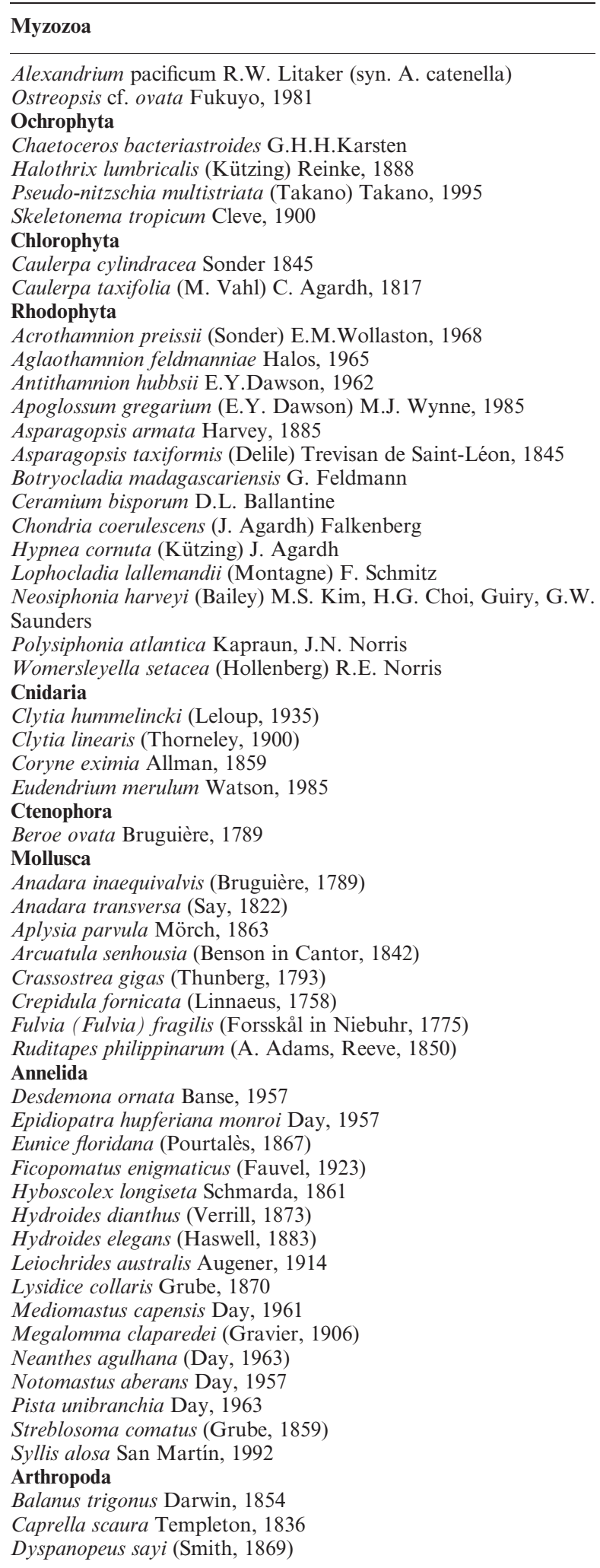

(Continues)

Copyright (C) 2015 John Wiley \& Sons, Ltd.
Table 1. (Continued)

Myzozoa

Paracartia grani Sars G.O., 1904

Penaeus semisulcatus De Haan, 1844 [in De Haan, 1833-1850]

Percnon gibbesi (H. Milne Edwards, 1853)

Pseudodiaptomus marinus Sato 1913

Rhithropanopeus harrisii (Gould, 1841)

Bryozoa

Bugula fulva Ryland, 1960

Chordata

Fistularia commersonii Rüppell, 1838

or absence of data). In addition, models were fitted with a negative binomial distribution to take into account the over-dispersed data (Bliss and Fisher, 1953). Both sampling sites and taxonomical groups were included as random effects in order to consider the spatial dependence of the data and potential bias introduced by non-homogeneous sampling across taxa. All the possible combinations of the three variables were examined to evaluate the fit of different predictor variables. The best fit of the models obtained was evaluated using the Akaike Information Criteria (AIC).

In order to explore the pattern of AS distribution across different habitats, a Multiple Correspondence Analysis (MCA) was applied on the matrix of AS-habitat interactions (matrix of presence-absence with 61 species and seven habitats). MCA analysis is the counterpart of principal component analysis for categorical data, which shows the underlying structure in the dataset. The MCA was performed using the $\mathrm{R}$ package FactoMineR (Husson et al., 2014).

\section{RESULTS}

\section{The dataset}

In total, 3899 species belonging to five kingdoms (Bacteria, Chromista, Protozoa, Plantae, and Animalia) and 29 phyla are listed in the LifeWatch database (Figure 1). Of these, 61 AS belonging to 11 phyla were recorded (Table 1), representing nearly $1.6 \%$ of the total number. Annelida was the most represented taxon in terms of AS (16 species), followed by Rhodophyta (14), Arthropoda (eight), and Mollusca (eight), together representing $75 \%$ of the observed AS. In the remaining seven groups (Myzozoa, Ochrophyta, 


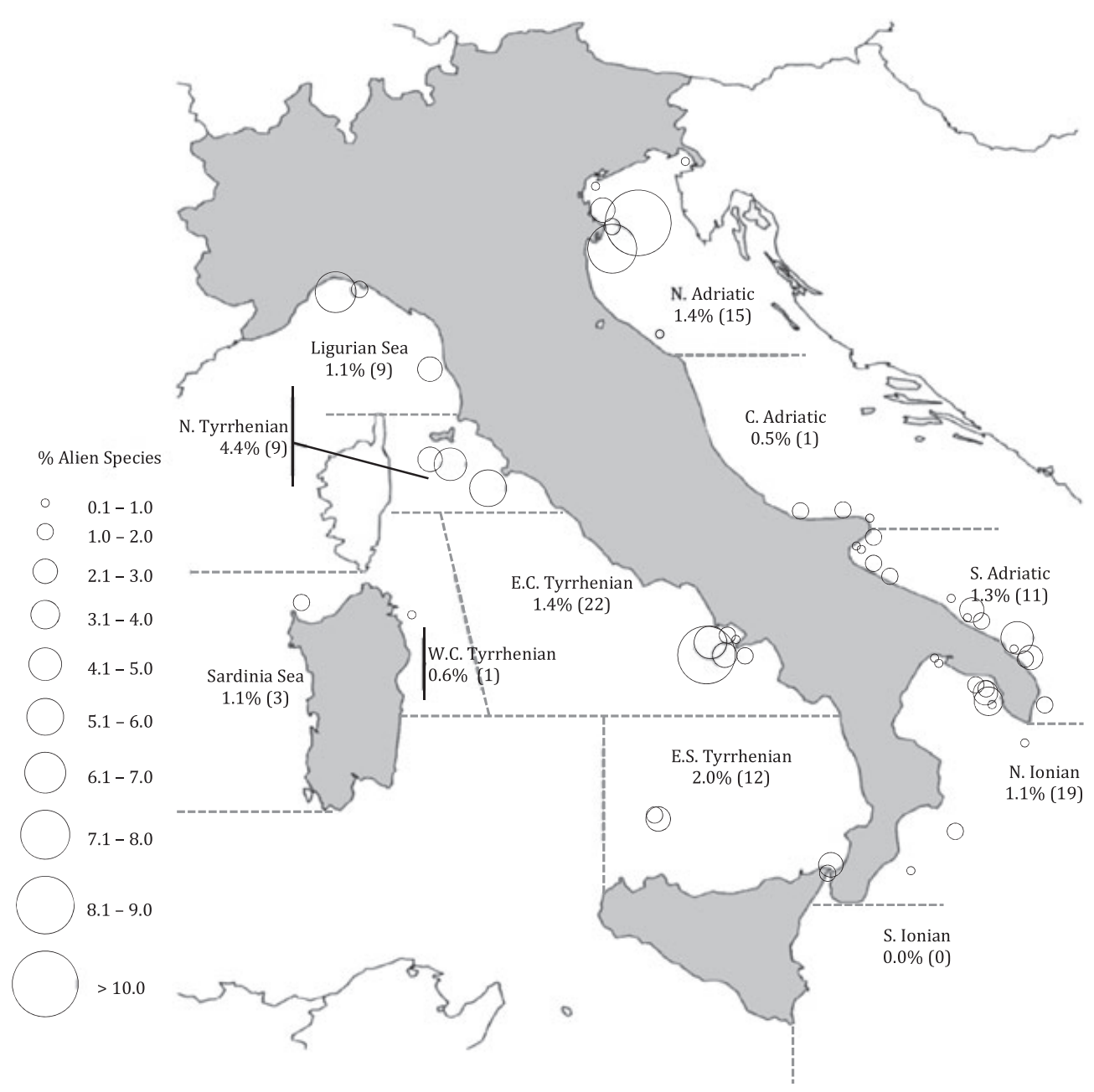

Figure 2. Distribution of marine sites and AS along the Italian coast. Circles: percentage of AS over species richness (R) for each sampling site; numbers: percentage of AS over R in each GMA; number between brackets: total number of AS recorded in each GMA.

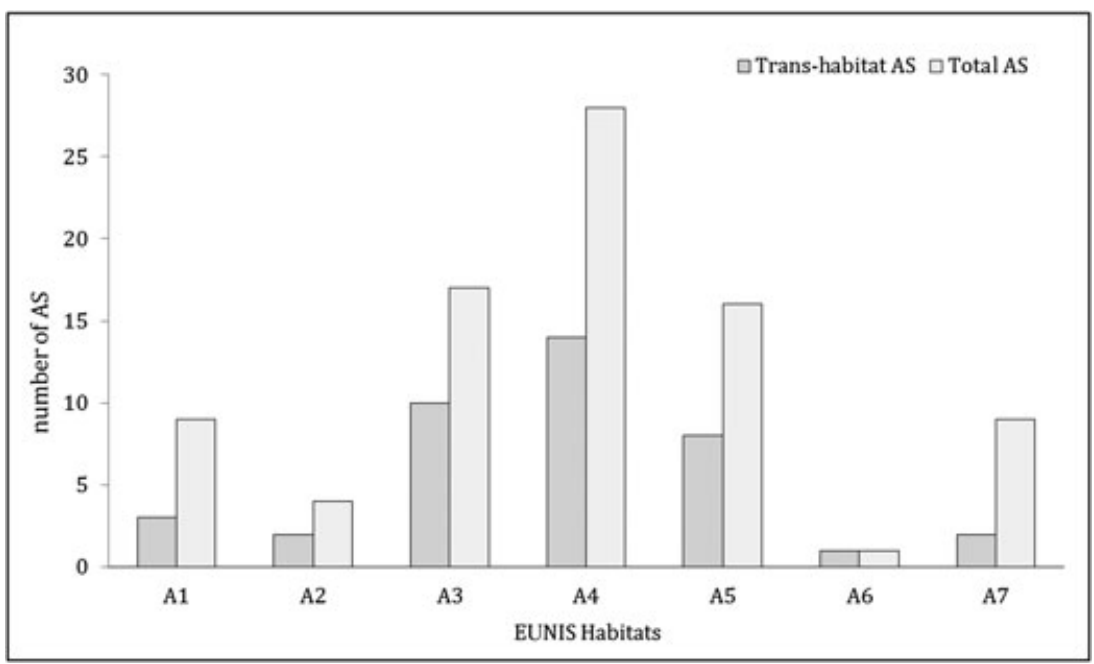

Figure 3. Distribution of total AS and trans-habitat AS in EUNIS Habitat level 2. A1, littoral rock and other hard substrata; A2, littoral sediment; A3, infralittoral rock and other hard substrata; A4 circalittoral rock and other hard substrata; A5, sublittoral sediment; A6, deep-sea bed; A7, pelagic water column. 
Table 2. Model selection according to the Akaike Information Criterion (AIC). The AIC was compared with different fitted models in order to identify the best explanatory model. The fixed term and degrees of freedom (d.f.) are reported for each model.

\begin{tabular}{lrl}
\hline Fixed effect & df & AIC \\
\hline Habitat+Rn & 12 & 361.418 \\
Habitat+Rn+GMA & 22 & 370.852 \\
Rn+GMA & 16 & 383.342 \\
Rn & 6 & 386.846 \\
Habitat & 11 & 400.77 \\
Habitat+GMA & 21 & 403.62 \\
GMA & 15 & 412.032 \\
Null model & 5 & 434.566 \\
\hline
\end{tabular}

Chlorophyta, Ctenophora, Cnidaria, Bryozoa, and Chordata), the number of AS ranged from one to four. No AS were detected in the remaining 18 phyla.

Figure 2 shows the distribution of AS in the investigated sites in the Italian seas, divided into Geographic Macro Areas (GMAs), according to Occhipinti-Ambrogi et al. (2011a). AS were found in all the GMAs except the southern Ionian Sea, with the highest percentage of AS over species richness detected in the northern Tyrrhenian Sea (4.4\%), followed by the southern Tyrrhenian ( $2 \%)$, eastern central Tyrrhenian and northern Adriatic (1.4\%).

Eighteen AS were detected in more than one GMA: in particular, the benthic seaweed species Acrothamnion preissii, Caulerpa cylindracea, Womersleyella setacea, Asparagopsis armata, and the hydroid Clytia linearis were detected in three

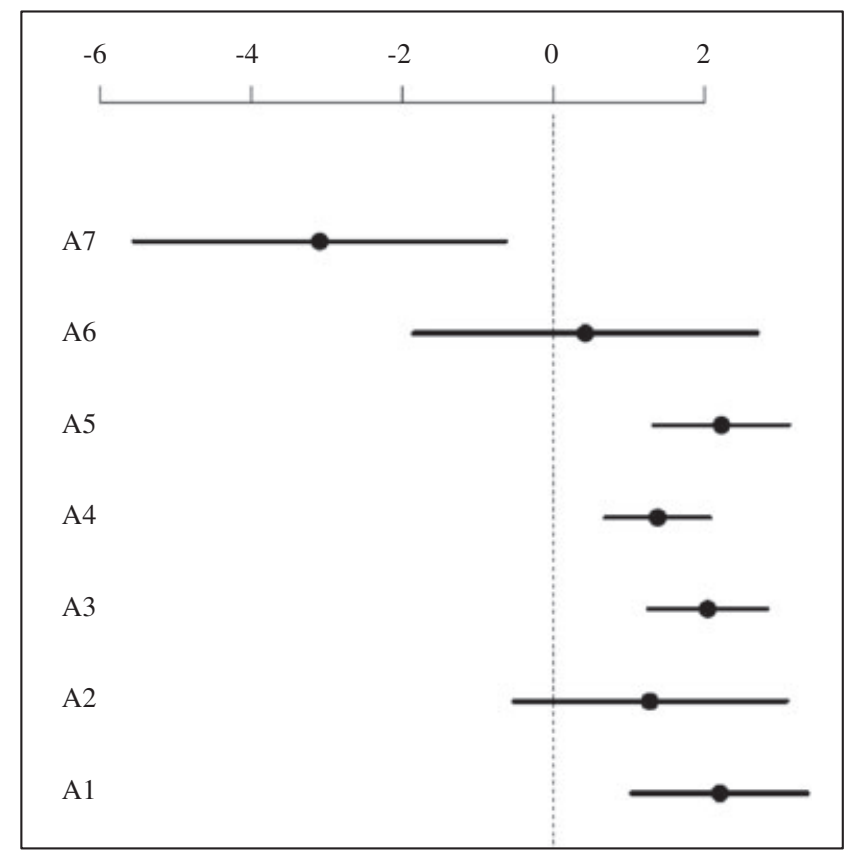

Figure 5. Regression coefficients obtained from GLMM for the seven EUNIS habitats included as factors. Circles represent estimated coefficients, while lines represent $95 \%$ confidence interval. A1, littoral rock and other hard substrata; A2, littoral sediment; A3, infralittoral rock and other hard substrata; A4 circalittoral rock and other hard substrata; A5, sublittoral sediment; A6, deep-sea bed; A7, pelagic water column.

GMAs. The remaining 13 species were detected in two GMAs.

AS were recorded in all habitats considered (Figure 3), with a maximum of 28 species on circalittoral hard substrata and a single AS on the deep-sea bed. Fifty-four AS were found in the 49

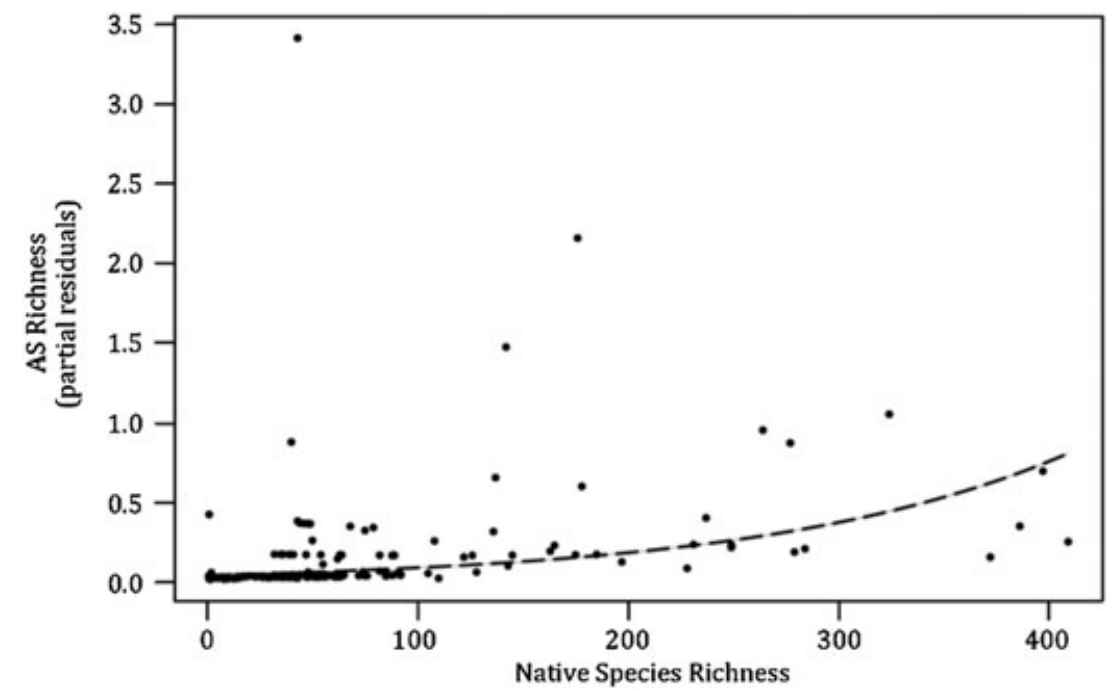

Figure 4. Relationships between native species richness and AS richness at site level for each taxonomic group and habitat EUNIS according to the results of GLMM. 


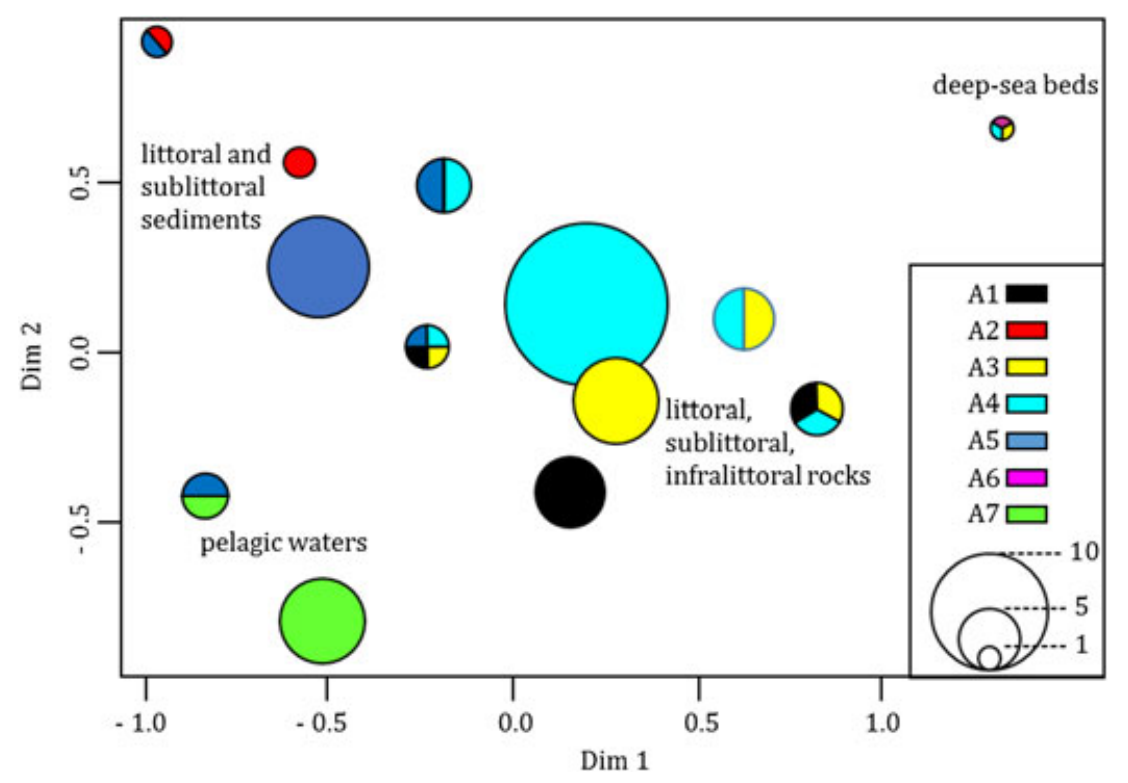

Figure 6. Multiple correspondence analysis (MCA) based on presence-absence matrix of AS. Colours represent different EUNIS Habitat (A1, littoral rock and other hard substrata; A2, littoral sediment; A3, infralittoral rock and other hard substrata; A4 circalittoral rock and other hard substrata; A5, sublittoral sediment; A6, deep-sea bed; A7, pelagic water column), where the species was found, while circle size is proportional to the number of species. The species are clustered according to habitat similarity.

sites of the benthic domain and nine in the 44 pelagic sites, with a prevalence of phytoplankton AS. In terms of proportions of the native species, the maximum percentage of AS $3.7 \%$ of the present species richness) was found on littoral hard substrata, and the minimum $(0.4 \%)$ on the deep-sea bed.

\section{Generalized linear models}

According to AIC, all the models performed better than the null model (Table 2). The best model describing AS richness took account of both native species richness $(\mathrm{Rn})$ and habitat but not GMAs as explanatory variables.

The model explicitly considering the difference in taxonomic coverage and spatial bias detected a significant $(P<0.001)$ and positive trend in increase of AS with increase in Rn (Figure 4). All habitats showed a significant relationship with AS richness (Wald $\mathrm{z}$ test $P<0.05$ ), except for infralittoral rock substrata and deep-sea beds. According to regression coefficients (Figure 5) and the Tukey test, the differences observed are due to a lower number of AS found in the pelagic water column compared with littoral rock and other hard substrata, infralittoral rock and other hard substrata, circalittoral rock and other hard substrata, and sublittoral sediment (Tukey test: $P<0.05$ in all the pairwise comparisons). Conversely, the other habitats showed no significant differences between them.

\section{Multivariate analysis of species-habitat interaction}

The ordination plot obtained from MCA (the first two axes shown account for $44.7 \%$ of the total variance) showed how species were assembled according to their habitat of occurrence (pelagic waters, soft substrata, hard substrata, deep-sea beds) (Figure 6). MCA highlighted three main groups of species, namely species found in a single habitat, species shared across similar habitat categories (i.e. between sublittoral and littoral sediments or among rocky substrata) and also species found across different habitats.

While 43 of the AS ( $70 \%$ of the total AS) were found within a specific habitat (EUNIS level 2), the others were shared between different habitats (trans-habitat AS). Circalittoral rock and other hard substrata showed the largest number of AS and the largest amount of trans-habitat AS (50\% of the total).

Of the nine AS found in the pelagic water column, Anadara inaequivalvis and Ruditapes philippinarum were also detected in sublittoral 

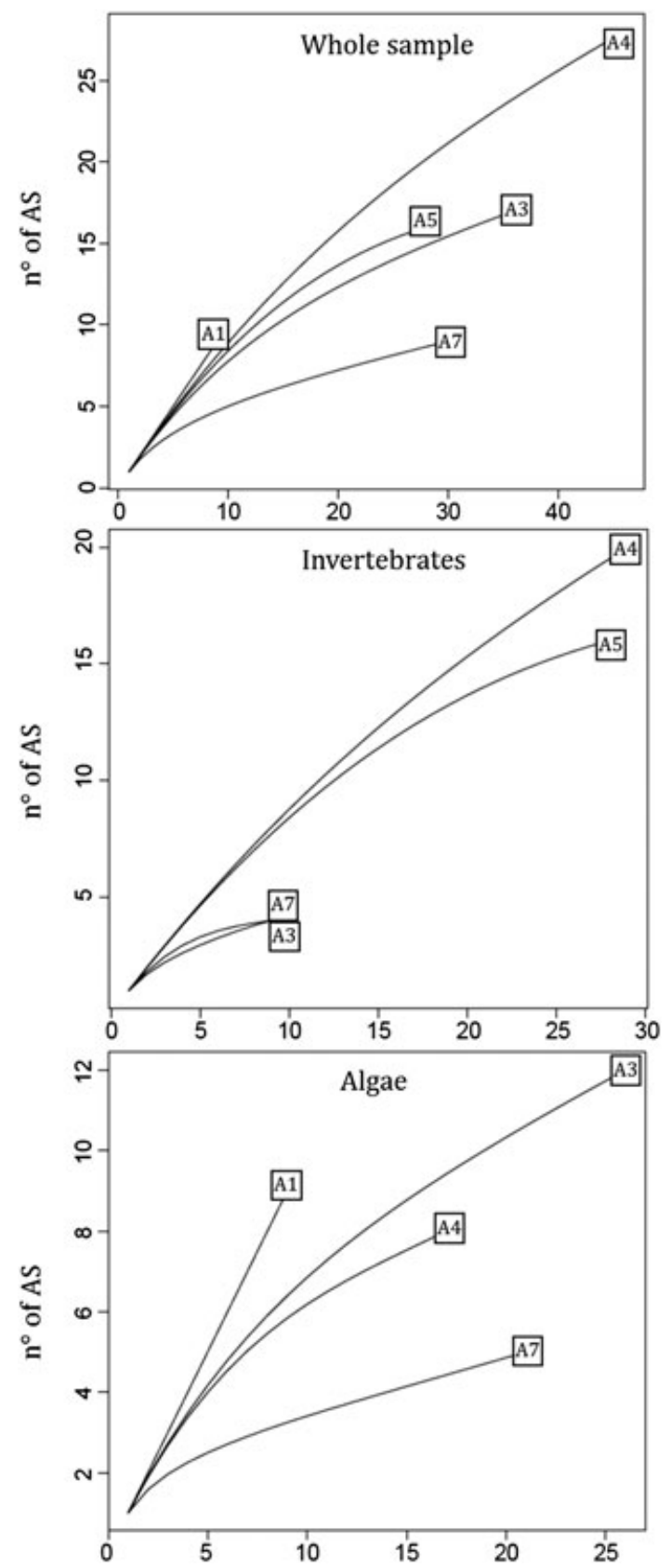

Figure 7. Rarefaction curves obtained as a count of AS against the sample size (number of sites) for the observed AS richness in the whole dataset, invertebrates and algae samples sub-datasets. On the " $y$ " axis the number of observed species and on the " $x$ " axis the sample size are reported. For Invertebrates EUNIS habitats A2 and A6 were excluded from the analysis due to the low sample size (4 and 1 respectively). A1, littoral rock and other hard substrata; A2, littoral sediment; A3, infralittoral rock and other hard substrata; A4 circalittoral rock and other hard substrata; A5, sublittoral sediment; A6, deep-sea bed; A7, pelagic water column.

sediments. Two polychaetes shared littoral and sublittoral sediment habitats while the polychaete Notomastus aberans was found both in sublittoral sediment and on circalittoral rock and other hard substrata. Littoral, sublittoral and infralittoral rocks shared the algae Acrothamnion preissii and Asparagopsis armata as well as, together with sublittoral sediments, Caulerpa cylindracea, and Womersleyella setacea. The hydrozoan Clytia linearis, the only AS found on the deep-sea bed, was also found on littoral and infralittoral rocks.

\section{Correlates of AS presence}

Sample-based rarefaction curves (cumulative count of AS against the number of sites, for homogeneous subsets of data) are reported in Figure 7, considering all the AS (whole sample) and the two most represented groups, invertebrates and algae.

When AS are considered as a whole, all the habitats but one (littoral rock and other hard substrata) showed a logarithmic trend of rarefaction curves. Sublittoral sediment tended towards a plateau while other habitats showed a continuous increase in the number of AS (marked up to 20 sample sites for circalittoral rock and other hard substrata).

Looking at rarefaction curves for invertebrate AS only, circa-littoral rock and other hard substrata still showed a constant increase in AS with the increase of the number of sampled sites. Conversely, pelagic water column and partially sublittoral sediments were close to a plateau. The situation changes when algal AS are considered and all habitats except littoral rock and other hard substrata began to show a tendency to decrease the slope of the curves. Infralittoral rock and other hard substrata also showed an evident decrease but it occurred at a higher number of sampled sites. Finally, for littoral rock and other hard substrata there was a marked and continuous increase in AS number with the number of sampled sites.

\section{DISCUSSION}

\section{A picture of marine AS presence across EUNIS habitats along the Italian coast}

Although the spread of AS is becoming an increasing problem, studies comparing the distribution of AS between habitats are surprisingly uncommon in the marine environment (Zaiko et al., 2007). Literature referring to the marine biota mainly focuses on the distributional traits of single invasive species in a few habitats 
(Piazzi and Cinelli, 2001; Zaiko et al., 2007; Gollasch et al., 2008; Baldacconi and Corriero, 2009; Piazzi and Balata, 2009; Olenina et al., 2010; de Caralt and Cebrian, 2013). Thus, the present paper represents the first analytical study on the occurrence and distribution of AS in a large number of marine habitats (EUNIS habitats) within the Mediterranean. Despite the dataset used here not presumably including all known AS and the geographical coverage being piecemeal, the paper provides a reasonably comprehensive overview of the distribution of AS in all the EUNIS habitats (second level) present along the Italian coast.

To date, current literature on the Mediterranean does not allow any distinction between the pool of AS inhabiting natural marine environments and those exclusive to harbours, polluted sites and lagoon environments. In recent reviews, Occhipinti-Ambrogi et al. (2011a, b) compute 164 AS (both marine and brackish) for the Italian coasts, corresponding to about $20 \%$ of the nonnative species reported in total for the Mediterranean Sea (GSA-SIBM, 2012). Most of them, however, were recorded from lagoons, coastal lakes, harbours and marine areas heavily exploited by human activities (Occhipinti-Ambrogi and Savini, 2003; Sfriso et al., 2009; Longo et al., 2012; Petrocelli et al., 2013; Cardone et al., 2014), which are hubs for biological invasions (Pérez-Ruzafa et al., 2011; Petrocelli et al., 2013), whereas the records of AS from natural environments are less common in the literature. The list of 61 AS in the present paper, exclusively referred to natural marine habitats, seems to indicate that, to date, most of the AS present along the Italian coast are closely associated to the hot spot areas of introduction, and only a small fraction of them spread across natural marine habitats.

The AS taxonomic analysis indicated invertebrates as the most represented group (about $62 \%$ of the total AS number). Such a result is in agreement with the current literature reviews for the Italian coasts, where this group includes about $80 \%$ of the known AS (Occhipinti-Ambrogi et al., $2011 \mathrm{a}$, b). In the marine environment, species extinctions caused by invertebrate AS are poorly documented (Gurevitch and Padilla, 2004; Pranovi et al., 2006; Briggs, 2007), while most of the literature refers to the effect on native community of non-native algal spread (Piazzi and Cinelli, 2000, 2001; Piazzi et al., 2005, 2012; Baldacconi and Corriero, 2009; de Caralt and Cebrian, 2013). Since the AS animal component is dominant within the whole Mediterranean Sea (Zenetos et al., 2010; 2012), the current scenario regarding the influence of invertebrate AS is particularly worthy of further study. Increasing the studies on the interactions between invertebrate AS and native communities is necessary, since sometimes the former are not immediately detected (such as worms and molluscs in sediments), but can lead to local replacement of species, for example in the case of the Manila clam Ruditapes philippinarum in the Venice lagoon (Pranovi et al., 2006).

In the framework of this study, AS occurred in all habitats and almost all geographic areas, albeit with different distributions. Most of them were detected in benthic environments (54 species), and only nine in the pelagic domain, in accordance with Occhipinti-Ambrogi et al. (2011a, b), reporting most of the AS within benthic habitats. This could be due to the different mechanisms of introduction, spreading and persistence of AS in these two different environments.

According to the statistical analysis, AS recorded during the present study could have been more numerous, since some marine habitats seemed to be still unsaturated. There were clear differences in the number of species observed with respect to the number of sites sampled and no habitat really reached a plateau (Figure 7). This is particularly evident on littoral, infralittoral and circalittoral rocks, thus indicating that these marine habitats could host an even larger number of AS. In contrast, the sublittoral sediment showed an initial logarithmic increase in the number of $\mathrm{AS}$, followed by a reduction in the curve slope very close to a plateau, thus suggesting that this habitat was unlikely to be able to host a much greater number of AS. The pelagic habitat showed a short steep slope in the rarefaction curves, suggesting a possible lower (or slower) propensity to host AS compared with benthic habitats. Many AS spread through pelagic propagules within ballast waters 
(Olenin et al., 2010; Gollasch et al., 2013), but they are very hard to find. In addition, Zenetos et al. (2010) highlighted the difficulty in documenting phytoplankton AS in the Mediterranean Sea, especially because of the scarce background knowledge on diversity of marine microalgae owing to their biological and ecological characteristics (e.g. ephemeral and patchy distribution, short-time occurrence) and relative difficulties in their sampling (e.g. resolution of sampling programmes, difficulty in preservation). The presence of heteromorphic life cycles in several microalgae (e.g. dinoflagellates, diatoms and raphidophytes), with alternating phases of vegetative planktonic and benthic life stages, highlights the continuum among habitats (pelagic and benthic) and the necessity of an integrated water/sediment approach in their study (Satta et al., 2010).

Within the benthic domain, the circalittoral rock and other hard substrata (in the LifeWatch database mostly represented by coralligenous assemblages) constitute the habitats with the greatest number of AS (eight algae, one ctenophore, two hydrozoans, nine polychaetes, five molluscs, two crustaceans, and one bryozoan) and with the highest native species richness as well. According to Byers and Noonburg (2003) the biodiversity of native and exotic species are often positively related at large-scale, but negatively correlated at small-scale. In the present study, including large-scale biodiversity data, a significant positive relationship between AS richness and native species richness was revealed by the GLMM analysis, thus suggesting a pattern that fits with the 'biodiversity increasing invasibility hypothesis' (Cohen and Carlton, 1998; Stohlgren et al., 2003). Furthermore, studies carried out in terrestrial environments at a regional scale have found that exotic species richness in plants is associated with high native plant species richness (Lonsdale, 1999; Stohlgren et al., 2006). At broader spatial scales, the physical complexity of natural community environments appears to reduce the resistance to the spread of AS provided by high species richness (Levine, 2000; Shea and Chesson, 2002). Hence, according to these studies, the combination of ecological processes and factors that maintain high native species richness in plant communities also increases the spread of AS.

Along the Italian coasts, the coralligenous biogenic habitat characterizes circalittoral and, partially, infralittoral hard substrata. It is a highly biologically differentiated marine community (Hong, 1982; Laborel, 1987) with more than 1500 species (Ballesteros, 2006), characterized by wide variations in invertebrate and algal composition in relation to increasing depth and varying ecological and edaphic conditions (Ferdeghini et al., 2000; Ballesteros, 2006; Bedini et al., 2014). The high number of AS found in circalittoral and infralittoral hard substrata could be related to the high biodiversity of coralligenous assemblages, enhanced by their environmental stability and habitat heterogeneity (Cocito, 2004; Ballesteros, 2006).

The importance of coralligenous outcrops is also due to the presence of numerous species of conservation interest. To date, more than 50 exclusive coralligenous invertebrate key-species have been reported in international biodiversity conventions and/or on European red lists (e.g. Spongia officinalis, Cladocora caespitosa, Corallium rubrum). Although pollution and increased sedimentation rates are recognized to be the main threats to coralligenous assemblages (Boudouresque et al., 1990), the spread of AS could represent an emerging threat, since it could lead to profound changes in the community by changing the pattern of distribution and abundance of native structuring species (Occhipinti-Ambrogi, 2000; Piazzi and Cinelli, 2000). As coralligenous outcrops represent one of the most important biodiversity hotspots in the Mediterranean, the loss of their unique characteristics would lead to significant threats to the entire littoral system (Piazzi et al., 2012).

The scenario changes among soft bottom habitats.

Native communities associated with sublittoral sediment habitat varies greatly in the presence of plant coverage, in particular seagrass (mainly Posidonia oceanica and Cymodocea nodosa), which is very important for their structural complexity, ecological function, and high levels of associated 
species richness (Klumpp et al., 1992; Mazzella et al., 1992). When plant coverage is lacking, native communities are much depleted in number of species, and mainly dominated by scavenger invertebrates. Although the sublittoral sediment habitat appeared to be close to reaching a balance in the number of AS (see rarefaction curves, Figure 7), the presence of 16 AS (two algae and 14 invertebrates) should be emphasized. According to the literature, seagrass represents the most suitable substrate for the spread of the invasive algae Caulerpa cylindracea and Womersleyella setacea (Piazzi and Cinelli, 2000, 2001; Piazzi and Balata, 2009). Present data, however, highlighted the dominance of invertebrates among AS associated with sublittoral sediments, with six species of polychaetes, five molluscs, and three crustaceans. Among them, Arcuatula senhousia is considered locally invasive along the Italian coast (Mistri et al., 2004) and it is able to alter sedimentary properties of soft bottoms, through the construction of byssal mats on the surface of sediments. Although the other identified invertebrate AS are not considered invasive, their spread in soft-bottom habitats may be considered as a potential threat, their interactions with native fauna still being unexplored. Along the coast of the Italian Peninsula, a well-known case refers to the North Adriatic, where repeated introductions of the commercial mollusc Ruditapes philippinarum has led to the depletion and local disappearance of the closely related native $R$. decussatus (Pranovi et al., 2006). In extra Mediterranean environments, however, a positive interaction between alien and native species in sublittoral sediment has also been reported. It regards the polychaete Marenzelleria sp., which has been described to positively affect the keystone species Zostera marina, by burying the seeds of the phanerogam, so reducing seed predation and facilitating seed germination (Delefosse and Kristensen, 2012).

In the framework of the present study, littoral sediment may be considered among the less rich in native species. The pool of data in the LifeWatch database referred to a considerable number of observations on a few sites, which if, on the one hand, did not allow the highlighting of trends on the species/area relationship (rarefaction curves), on the other hand provided an indication of the occurrence of AS in this habitat. The AS recorded were all invertebrates, three polychaetes and one arthropod, reflecting the capacity of this environment to hosting animals more than anything else. The low number of AS recorded may be explained by the great temporal variability that characterizes littoral communities, owing to the action of waves and to the seasonal hydrological variations.

Even the deep-sea habitats had AS, despite being generally imagined as the best preserved and by far the most distant from the hubs of introduction. In the present paper a single hydroid AS (Clytia linearis) was identified, with large ecological plasticity and trans-habitat distribution. The species is one of the most common Mediterranean hydroids on shallow hard bottoms (Bouillon et al., 2004), and may be considered as invasive. To date, however, no data are available about its possible influence on native communities.

As expected, the MCA showed how most of the AS occupied the same position on the factorial map, because they were associated with one habitat. However, a large fraction of the benthic AS reported in the present work (about $30 \%$ of the total AS recorded) showed a trans-habitat distribution (Figure 6), since these species were able to colonize pelagic and benthic compartments (both hard and soft bottoms) within a wide bathymetric range. The ability to colonize habitats characterized by wide variations in edaphic and bathymetric conditions could reflect the intrinsic characteristics of the species in their native range, but it could also be considered as a measure of the potential invasiveness of the AS. The circalittoral habitat presented the highest number of trans-habitat AS (14) in addition to a greater AS species richness, providing a further indication of its vulnerability to biological invasions.

From a geographical point of view, a higher concentration of AS could have been expected in GMAs including marine sites close to areas characterized by intense maritime traffic (e.g. harbours and lagoons). However, although a high number of AS were recorded in some GMAs, the GLMM did not support a geographical effect on 
their localization, probably because the present analysis included only natural marine environments and not all the GMA were uniformly represented. Indeed, while the introduction of AS in marine environments could be mainly due to the presence of point entry vectors, their spread and persistence could be related to biotic and ecological factors regulating the AS success.

The results of this macro-ecological study have highlighted some large-scale features not detectable by studies carried out on a single species or habitat, and contributed towards the development of effective management strategies that approach the impacts of AS from an ecosystem perspective.

Furthermore, it revealed the occurrence of a positive relationship between alien and native species richness in marine environments. This has various possible explanations, from the intrinsic characteristics of the system allowing it to sustain a demographically successful AS population, to the presence of external factors acting on the community (Davis et al., 2000; Zaiko et al., 2007).

Even though the introduction of AS locally increases species richness (Gurevitch and Padilla, 2004; Briggs, 2007), in most cases invasions have a negative effect, since the receiving systems become ecologically unbalanced. According to several authors (Dick et al., 2002; Gurevitch and Padilla 2004; Piscart et al., 2009; Hänfling et al., 2011), the most serious consequences are changes in native species composition due to extirpation of local native populations. However, what invaded ecosystems really lose is not biodiversity, but biological uniqueness, integrity, and ecological functions (Rilov, 2009). On the other hand, studies on positive effects of AS are receiving increasing attention (Thieltges et al., 2006; Schlaepfer et al., 2011; McLaughlan et al., 2013; Thomsen et al., 2014) and some authors (Katsanevakis et al., 2014) suggest that the positive impacts of AS may be underestimated.

The occurrence of AS in habitats not traditionally considered hubs for biological invasions suggests that the patterns of introduction and persistence of AS probably follow different models. It must be assumed that the AS present in marine communities are not so much the result of 'point introductions', but rather the effect of expansions of species previously introduced into different environments (e.g. lagoons, ports, mussel plants). Consequently, from a conservation point of view, two different monitoring models should be distinguished, the first aimed at providing an early warning of the arrival of AS in the hot spots of introduction and a second aimed at evaluating the success of these species in marine environments. Thus, the present study highlighted the importance of designing monitoring strategies suitable for different habitats, from those historically considered AS hubs (mainly transitional waters), to the biologically pristine, rich, and diverse benthic ones (Otero et al., 2013). The importance of AS monitoring programmes on benthic habitats is also supported by the need to assess the potential impact of AS on key species, among which is the pool of bioconstructors (mainly algae) able to sustain specific assemblages. Besides having an indisputable ecological and conservation value, diverse benthic communities provide economic benefits such as providing popular dive experiences.

Monitoring programmes should lead to conservation strategies that allow the possibility of mitigating biological invasions, but studies in marine habitats are still in their infancy. While research into the vulnerability of freshwater and lagoon environments leads to the conclusion that biological invasions can potentially be controlled and limited by mitigating human activities in the environment (Pyšek et al., 2010; Boggero et al., 2014), it is still difficult to determine the most significant correlates in marine habitats so as to set conservation priorities. Furthermore pollution due to increased nutrients plays a crucial role, since the growth of invasive alien seaweed on marine hard bottom is enhanced by nutrient enrichment, leading to strong impacts on native macroalgal assemblages (Piazzi et al., 2012).

Ekebom (2013) suggested that the process of incorporating the ecosystem approach into marine and environmental policies is 'a long and winding road' and to date, considering the unpredictability of the invasion process, what can be done is to improve methods to detect impacts and implement 
experimental and mensurative studies at different spatial and temporal scales.

In the present paper, the EUNIS habitat code (eight Mediterranean marine habitats) has been used, but the level of detail should be much higher (e.g. by choosing other habitat codes or more specific levels of the EUNIS code). Moving forward in this direction seems fruitful, allowing description of the relationship between AS and habitats at a higher level, and investigating more thoroughly what makes marine habitats able to accommodate AS.

To date, the only realizable recommendations are, on one hand, to stimulate the ability of ecosystems to intrinsically resist biological invasions by improving environmental quality, on the other hand, to prevent further invasions. These recommendations are more significant in the light of the strategic plans that Mediterranean countries are currently preparing, all of which consider AS monitoring as an important issue.

\section{ACKNOWLEDGEMENTS}

We acknowledge the help provided by the LifeWatch network, especially with the alien showcase, as it allowed us to use the dataset to perform the analyses for the present contribution. We thank two anonymous reviewers and the editor John Baxter for constructive suggestions greatly improving the strength of the manuscript.

\section{REFERENCES}

Argyrou M, Demetropoulos A, Hadjichristophorou M. 1999. Expansion of the macroalga Caulerpa racemosa and changes in soft bottom macrofaunal assemblages in Moni Bay, Cyprus. Oceanologica Acta 22: 517-528.

Athanasiadis A. 1997. North Aegean marine algae. Womersleyella setacea (Hollenberg) R.E. Norris (Rhodophyta, Ceramiales). Botanica Marina 40: 473-476.

Baldacconi R, Corriero G. 2009. Effects of the spread of the alga Caulerpa racemosa var. cylindracea on the sponge assemblage from coralligenous concretions of the Apulian coast (Ionian Sea, Italy). Marine Ecology 30: 337-345.

Ballesteros E. 2006. Mediterranean coralligenous assemblages: a synthesis of present knowledge. Oceanography and Marine Biology: An Annual Review 44: 123-195.
Basset A, Los W. 2012. Biodiversity e-Science: LifeWatch, the European infrastructure on biodiversity and ecosystem research. Journal of Plant Biosystems 146: 780-782.

Bedini R, Bonechi L, Piazzi L. 2014. Spatial and temporal variability of mobile macro-invertebrate assemblages associated to coralligenous habitat. Mediterranean Marine Science 15: 302-312. DOI: 10.12681/mms.442.

Bliss CI, Fisher RA. 1953. Fitting the negative binomial distribution to biological data - note on the efficient fitting of the negative binomial. Biometrics 9: 176-200.

Boero F. 2002. Ship-driven biological invasions in the Mediterranean Sea. In alien marine organisms introduced by ships in the Mediterranean and Black seas. CIESM Workshop Monographs 20: 87-91.

Boggero A, Basset A, Austonia M, Barbone B, Bartolozzi L, Bertani I, Cattaneo A, Cianferoni F, Corriero G, Dörrh AM, et al. 2014. Weak effects of habitat type on susceptibility to invasive freshwater species: an Italian case study. Aquatic Conservation: Marine and Freshwater Ecosystems, DOI: 10.1002/aqc.2450. EDITOR: Latest info (this journal) required

Bolker BM, Brooks ME, Clark CJ, Geange SW, Poulsen JR, Henry M, Stevens H, White JS. 2009. Generalized linear mixed models: a practical guide for ecology and evolution. Trends in Ecology and Evolution 24: 127-135.

Boudouresque CF, Verlaque M. 2002. Biological pollution in the Mediterranean Sea: invasive versus introduced macrophytes. Marine Pollution Bulletin 44: 32-38.

Boudouresque CF, Meinesz A, Ballesteros E, Ben Maiz N, Boisset F, Cinelli F, Cirik S, Cormaci M, Jeudy de Grissac A, et al. 1990. Livre Rouge 'Gérard Vuignier' des végétaux, peuplements et paysages marins menacés de Méditerranée. MAP Technical Report Series, 43. Athens: UNEP/IUCN/ GIS Posidonie, 1-250.

Bouillon J, Medel MD, Pages F, Gili J-M, Boero F, Gravili C. 2004. Fauna of the Mediterranean Hydrozoa. Scientia Marina 68: 5-449.

Boxshall GA, Mees J, Costello MJ, Hernandez F, Gofas S, Hoeksema BW, Klautau M, Kroh A, Paulay G, Poore G, et al. 2014. World register of marine species. Available from http://www.marinespecies.org at VLIZ. Accessed 2014-2015.

Briggs JC. 2007. Marine biogeography and ecology: invasions and introductions. Journal of Biogeography 34: 193-198.

Byers JE, Noonburg EG. 2003. Scale dependent effects of biotic resistance to biological invasion. Ecology 84: 1428-1433.

Cardone F, Corriero G, Fianchini A, Gravina MF, Nonnis Marzano C. 2014. Biodiversity of transitional waters: species composition and comparative analysis of hard bottom communities from the south-eastern Italian coast. Journal of the Marine Biological Association of the United Kingdom 94: 25-34.

Carlton JT. 1985. Transoceanic and interoceanic dispersal of coastal marine organisms: the biology of ballast water. Oceanography and Marine Biology: An Annual Review 23: 313-371.

Chapin FS, Sala OE, Burke IC, Grime JP, Hooper DU, Lauenroth WK, Lombard A, Mooney HA, Mosier AR, Naeem S, et al. 1998. Ecosystem consequences of changing biodiversity. BioScience 48: 45-52.

Cocito S. 2004. Bioconstruction and biodiversity: their mutual influence. Scientia Marina 68: 137-144. 
Cohen AN, Carlton JT. 1998. Accelerating invasion rate in a highly invaded estuary. Science 279: 555-558.

Colautti RI, Grigorovich IA, MacIsaac HJ. 2006. Propagule pressure: a null model for biological invasions. Biological Invasions 8: 1023-1037.

Coll M, Piroddi M, Albouy C, Ben Rais Lasram F, Cheung WWL, Christensen V, Karpouzi VS, Guilhaumon F, Mouillot D, Paleczny M, et al. 2012. The Mediterranean Sea under siege: spatial overlap between marine biodiversity, cumulative threats and marine reserves. Global Ecology and Biogeography 21: 465-480.

Costello MJ, Coll M, Danovaro R, Halpin P, Ojaveer H, Miloslavich P. 2010. A census of marine biodiversity knowledge, resources, and future challenges. PLOS ONE 5: e12110.

Davis MA, Grime JP, Thompson K. 2000. Fluctuating resources in plant communities: a general theory of invisibility. Journal of Ecology 88: 528-534.

de Caralt S, Cebrian E. 2013. Impact of an invasive alga (Womersleyella setacea) on sponge assemblages: compromising the viability of future populations. Biological Invasions 15: 1591-1600.

Delefosse M, Kristensen E. 2012. Burial of Zostera marina seeds in sediment inhabited by three polychaetes: laboratory and field studies. Journal of Sea Research 71: 41-49.

Dick JTA, Platvoet D, Kelly DW. 2002. Predatory impact of the freshwater invader Dikerogammarus villosus (Crustacea: Amphipoda). Canadian Journal of Fish and Aquatic Sciences 59: 1078-1084.

Ekebom J. 2013. The long and winding road of the ecosystem approach into marine environmental policies. Aquatic Conservation: Marine and Freshwater Ecosystems 23: 1-6.

Elton CS. 1958. The Ecology of Invasion by Animals and Plants. Methuen: London.

Ferdeghini F, Acunto S, Cocito S, Cinelli F. 2000. Variability at different spatial scales of a coralligenous assemblage at Giannutri Island (Tuscan Archipelago, northwest Mediterranean). Hydrobiologia 440: 27-36.

Fournier DA, Skaug HJ, Ancheta J, Ianelli J, Magnusson A, Maunder M, Nielsen A, Sibert J. 2012. AD model builder: using automatic differentiation for statistical inference of highly parameterized complex nonlinear models. Optimization Methods and Software 27: 233-249.

Galil BS. 2007. Seeing red: alien species along the Mediterranean coast of Israel. Aquatic Invasions 2: 281-312.

Gollasch S, Cowx IG, Nunn AD. 2008. Environmental impacts of alien species in aquaculture. Progetto IMPASSE, relazione del marzo 2008, 150.

Gollasch S, Minchin D, Galil B, Occhipinti-Ambrogi A, Marchini A, Olenin S. 2013. Invasive alien species. VECTORS fact sheet series. http://www.marine-vectors. eu/pdf/FS-12_general_aliens.pdf.

Gravez V, Ruitton S, Boudouresque CF, Meinesz A, Scabbia G, Verlaque M. 2001. Fourth International Workshop on Caulerpa taxifolia. GIS Posidonie Publishers: France.

GSA-SIBM. 2012. Specie aliene rinvenute nei mari Italiani. Versione 1.2. http://www.sibm.it.

Gurevitch J, Padilla DK. 2004. Are invasive species a major cause of extinctions? Trends in Ecology and Evolution 19: $470-474$
Hänfling B, Edwards F, Gherardi F. 2011. Invasive alien crustaceans: dispersal, establishment, impact and control. Bio Control 56: 573-595.

Hayes KR, Barry SC. 2008. Are there any consistent predictors of invasion success? Biological Invasions 10: 483-506.

Herbold B, Moyle PB. 1986. The ecology of the Sacramento-San Joaquin delta: a community profile. US Fish and Wildlife Service 85(7.22): 106 pp.

Holdgate MW. 1986. Summary and conclusions: characteristics and consequences of biological invasions. Philosophical Transactions of the Royal Society, B: Biological Sciences 314: 733-742.

Hong JS. 1982. Contribution à l'étude des peuplements d'un fond de concrétionnement Coralligène dans la région marseillaise en Méditerranée nord-occidentale. Bulletin of Kordi 4: 27-51.

Hulme PE. 2007. Biological invasions in Europe: drivers, pressures, states, impacts and responses. In Biodiversity Under Threat, Hester R, Harrison RM (eds). Cambridge University Press: Cambridge; 56-60.

Hulme PE. 2009. Trade, transport and trouble: managing invasive species pathways in an era of globalization. Journal of Applied Ecology 46: 10-18.

Husson F, Josse J, Le S, Mazet J. 2014. FactoMineR: Multivariate Exploratory Data Analysis and Data Mining with R. R package version 1.26. http://CRAN.R-project. org $/$ package $=$ FactoMineR .

IUCN. 2000. IUCN Guidelines for the Prevention of Biodiversity Loss Caused by Alien Invasive Species. As approved by 51st Meeting of Council, February 2000. Aliens 11 Special Issue.

Katsanevakis S, Gatto F, Zenetos A, Cardoso AC. 2013. How many marine aliens in Europe? Management of Biological Invasions 4: 37-42.

Katsanevakis S, Wallentinus I, Zenetos A, Leppäkoski E, Çinar ME, Oztürk B, Grabowski M, Golani D, Cardoso ÁC. 2014. Impacts of invasive alien marine species on ecosystem services and biodiversity: a pan-European review. Aquatic Invasions 9: 391-423.

Kettunen M, Genovesi P, Gollasch S, Pagad S, Starfinger $\mathrm{U}$, ten Brink P, Shine C. 2009. Technical support to EU strategy on invasive species (IAS) - Assessment of the impacts of IAS in Europe and the EU (final module report for the European Commission). Institute for European Environmental Policy (IEEP): Brussels, Belgium.

Klumpp DW, Salita-Espinosa JS, Fortes MD. 1992. The role of epiphytic periphyton and macroinvertebrate grazers in the trophic flux of a tropical seagrass community. Aquatic Botany 45: 327-349.

Laborel J. 1987. Marine biogenic constructions in the Mediterranean, a review. Scientific Reports of Port-Cros National Park 13: 97-127.

Levine JM. 2000. Plant diversity and biological invasions: relating local process to community pattern. Science $\mathbf{2 8 8}$ : $852-854$.

Levine JM, Adler PB, Yelenik SG. 2004. A meta-analysis of biotic resistance to exotic plant invasion. Ecology Letters 7: 975-989.

Li HW, Rossignol PA, Castillo G. 2000. Risk analysis of species introductions: insights from qualitative modelling. In Non Indigenous Freshwater Organisms - Vectors, Biology, 
and Impacts, Claudi R, Leach $\mathrm{JH}$ (eds). Lewis Publishers: USA; 431-447.

Lodge DM. 1993. Biological invasions: lessons for ecology. Trends in Ecology and Evolution 8: 133-137.

Longo C, Pontassuglia C, Corriero G, Gaino E. 2012. Life-cycle traits of Paraleucilla magna, a calcareous sponge invasive in a coastal Mediterranean basin. PLOS ONE 7: e42392.

Lonsdale WM. 1999. Global patterns of plant invasions and the concept of invasibility. Ecology 80: 1522-1536.

Lotze HK, Lenihan HS, Bourque BJ, Bradbury RH, Cooke RG, Kay MC, Kidwell SM, Kirby MX, Peterson $\mathrm{CH}$, Jackson JBC. 2006. Depletion, degradation, and recovery potential of estuaries and coastal seas. Science 312: 1806-1809.

Mack RN, Simberloff D, Lonsdale WM, Evans H, Clout M, Bazzaz F. 2000. Biotic invasions: causes, epidemiology, global consequences, and control. Ecological Applications 10: $689-710$.

Maron JL, Connors PG. 1996. A native nitrogen-fixing shrub facilitates weed invasion. Oecologia 105: 302-312.

Mazzella L, Buia MC, Gambi MC, Lorenti M, Russo GF, Scipione MB, Zupo V. 1992. Plant-animal trophic relationships in the Posidonia oceanica ecosystem of Mediterranean Sea: a review. In Plant-Animal Interactions in the Marine Benthos, John DM, Hawkins SJ, Price JH (eds). Systematic association special volume, Clarendon Press: Oxford; 165-187.

McLaughlan C, Gallardo B, Aldridge DC. 2013. How complete is our knowledge of the ecosystem services impacts of Europe's top 10 invasive species? Acta Oecologica 54: 119-130.

Mistri M, Rossi R, Fano E. 2004. The spread of an alien bivalve Musculista senhousia in the Sacca di Goro Lagoon Adriatic Sea, Italy. Journal of Molluscan Studies 70: 257-261.

Moyle PB, Light T. 1996. Biological invasions of fresh water: empirical rules and assembly theory. Biological Conservation 78: 149-161.

Nellemann C, Hain S, Alder J. 2008. Rapid response assessment in dead water - merging of climate change with pollution, over-harvest, and infestations in the world's fishing grounds. United Nations Environment Programme, GRID-Arendal, Norway.

Nilsson C, Grelsson G. 1995. The fragility of ecosystems: a review. Journal of Applied Ecology 32: 677-692.

Occhipinti-Ambrogi A. 2000. Biotic invasions in the Lagoon of Venice: ecological considerations. Biological Invasions 2: 165-176.

Occhipinti-Ambrogi A, Savini D. 2003. Biological invasions as a component of global change in stressed marine ecosystems. Marine Pollution Bulletin 46: 542-551.

Occhipinti-Ambrogi A, Marchini A, Cantone G, Castelli A, Chimenz C, Cormaci M, Froglia C, Furnari G, Gambi MC, Giaccone G, et al. 2011a. Alien species along the Italian coasts: an overview. Biological Invasions 13: 215-237.

Occhipinti-Ambrogi A, Marchini A, Cantone G, Castelli A, Chimenz C, Cormaci M, Froglia C, Furnari G, Gambi MC, Giaccone G, et al. 2011b. Erratum to: Alien species along the Italian coasts: an overview. Biological Invasions 13: 531-532.

Oksanen J, Guillaume Blanchet F, Kindt R, Legendre P, Minchin PR, O’Hara RB, Simpson GL, Solymos P, Stevens
MHH, Wagner H. 2013. Vegan: Community Ecology Package. R package version 2.0-10. http://CRAN. R-project.org/package=vegan.

Olenin S, Alemany F, Cardoso AC, Gollasch S, Goulletquer P, Lehtiniemi M, McCollin $\mathrm{T}$, Minchin D, Miossec L, Occhipinti-Ambrogi A, et al. 2010. Marine Strategy Framework Directive Task Group 2 Report: Non-indigenous species JRC Scientific and Technical Reports Office for Official Publications of the European Communities: Luxembourg. ISBN 978-92-79-15655-7. 44.

Olenina I, Wasmund N, Hajdu S, Jurgensone I, Gromisz S, Kownacka J, Toming K, Vaiciūtè D, Olenin S. 2010. Assessing impacts of invasive phytoplankton: the Baltic sea case. Marine Pollution Bulletin 60: 1691-1700.

Otero M, Cebrian E, Francour P, Galil B, Savini D. 2013. Monitoring Marine Invasive Species in Mediterranean Marine Protected Areas (MPAs): A strategy and practical guide for managers. IUCN: Malaga, Spain.

Paavola M, Olenin S, Leppäkoski E. 2005. Are invasive species most successful in habitats of low native species richness across European brackish water seas? Estuarine, Coastal and Shelf Science 64: 738-750.

Pérez-Ruzafa Á, Marcos C, Pérez-Ruzafa IM. 2011. Recent advances in coastal lagoons ecology: evolving old ideas and assumptions. Transitional Waters Bulletin 5: 50-74.

Petrocelli A, Cecere E, Verlaque M. 2013. Alien marine macrophytes in transitional water systems: new entries and reappearances in a Mediterranean coastal basin. BioInvasion Records 3: 177-184.

Piazzi L, Balata D. 2009. Invasion of alien macroalgae in different Mediterranean habitats. Biological Invasions 11: 193-204.

Piazzi L, Cinelli F. 2000. Effects of the spread of the introduced Rhodophyceae Acrothamnion preissii and Womersleyella setacea on the macroalgal community of Posidonia oceanica rhizomes in the western Mediterranean Sea. Cryptogamie Algologie 21: 291-300.

Piazzi L, Cinelli F. 2001. Distribution and dominance of two introduced turf-forming macroalgae on the coast of Tuscany, Italy, north-western Mediterranean Sea in relation to different habitats and sedimentation. Botanica Marina 44: 509-520.

Piazzi L, Meinesz A, Verlaque M, Akçali B, Antolic B, Argyrou M, Balata D, Ballesteros E, Calvo S, Cinelli F, et al. 2005. Invasion of Caulerpa racemosa var. cylindracea (Caulerpales, Chlorophyta) in the Mediterranean Sea: an assessment of the spread. Cryptogamie Algologie 26: 189-202.

Piazzi L, Gennaro P, Balata D. 2012. Threats to macroalgal coralligenous assemblages in the Mediterranean Sea. Marine Pollution Bulletin 64: 2623-2629.

Piscart C, Dick JTA, McCrisken D, MacNeil C. 2009. Environmental mediation of intraguild predation between the freshwater invader Gammarus pulex and the native $G$. duebeni celticus. Biological Invasion 11: 2141-2145.

Pranovi F, Franceschini G, Casale M, Zucchetta M, Torricelli P, Giovanardi O. 2006. An ecological imbalance induced by a non-native species: the Manila Clam in the Venice Lagoon. Biological Invasions 8: 595-609.

Pyšek P, Chytrý M, Jarošík V. 2010. Habitats and land use as determinants of plant invasions in the temperate zone of Europe. In Bioinvasions and Globalization: Ecology, Economics, Management and Policy, Perrings C, Mooney 
HA, Williamson M (eds). Oxford University Press: Oxford; 66-79.

Quignard JP, Tomasini JA. 2000. Mediterranean fish biodiversity. Biologia Marina Mediterranea 3: 1-66.

R Core Team. 2014. R: A language and environment for statistical computing. R Foundation for Statistical Computing: Vienna, Austria. URL http://www.R-project.org/.

Rejmanek M. 1989. Invasibility of plant communities. In Biological Invasions: a Global Perspective, Drake JA, Mooney HA, di Castri F, Groves RH, Kruger FJ, Rejmanek M, Williamson M (eds). Wiley: Chichester; 369-388.

Rejmanek M. 2000. Invasive plants: approaches and predictions. Australian Ecology 25: 497-506.

Ricciardi A. 2001. Facilitative interactions among aquatic invaders: is an 'invasional meltdown' occurring in the Great Lakes? Canadian Journal of Fisheries and Aquatic Sciences 58: $2513-2525$.

Ricciardi A, MacIsaac HJ. 2008. The book that began invasion ecology. Nature 452: 34.

Richardson DM, Allsopp J, D'Antonio CM, Milton SJ, Rejmanek M. 2000. Plant invasions - the role of mutualisms. Biological Reviews of the Cambridge Philosophical Society 75: 65-93.

Rilov G. 2009. The integration of invasive species into marine ecosystems. In Biological Invasions in Marine Ecosystems: Ecological, Management, and Geographic Perspectives, Rilov G, Crooks JA (eds). Springer Verlag: Berlin; 240-244.

Romanuk TN, Kolasa J. 2005. Resource limitation, biodiversity, and competitive effects interact to determine the invasibility of rock pool microcosms. Biological Invasions 7: 711-722.

Satta CT, Angles S, Garcés E, Lugliè A, Padedda BM, Sechi N. 2010. Dinoflagellate cysts in recent sediments from two semi-enclosed areas of the western Mediterranean Sea subject to high human impact. Deep-Sea Research. Part 2. Topical Studies in Oceanography 57: 256-267.

Schlaepfer MA, Sax DF, Olden JD. 2011. The potential conservation value of non-native species. Conservation Biology 25: 428-437.

Sfriso A, Curiel D, Rismondo A. 2009. The Lagoon of Venice. In Flora and Vegetation of the Italian Transitional Water Systems, Cecere E, Petrocelli A, Izzo G, Sfriso A (eds). CoRiLa, Stampa Multigraf: Spinea, Venezia; 17-80.

Shea K, Chesson P. 2002. Community ecology theory as a framework for biological invasions. Trends in Ecology and Evolution 17: 170-176.

Simberloff D. 2014. Biological invasions: impacts, management, and controversies. In Controversies in Science and Technology, Volume 4. From Sustainability to Surveillance, Kleinman DL, Cloud-Hansen KA (eds). Oxford University Press: New York; 211-227.

Simberloff D, Von Holle B. 1999. Positive interactions of nonindigenous species: invasional meltdown? Biological Invasions 1: 21-32.

Stachowicz JJ, Whitlatch RB. 1999. Species diversity and invasion resistance in a marine ecosystem. Science 286: 1577-1579.

Stohlgren TJ, Barnett DT, Kartesz JT. 2003. The rich get richer: patterns of plant invasions in the United States. Frontiers in Ecology and the Environment 1: 11-14.
Stohlgren T, Jarnevich C, Chong GW, Evangelista PH. 2006. Scale and plant invasions: a theory of biotic acceptance. Preslia 78: 405-426.

Streftaris N, Zenetos A. 2006. Alien marine species in the Mediterranean - the 100 'worst invasives' and their impact. Mediterranean Marine Science 7: 87-118.

Thieltges DW, Strasser M, Reise K. 2006. How bad are invaders in coastal waters? The case of the American slipper limpet Crepidula fornicata in western Europe. Biological Invasions 8: 1673-1680.

Tilman D. 1997. Community invisibility, recruitment limitation, and grassland biodiversity. Ecology 78: 81-92.

Thomsen MS, Byers JE, Schiel DR, Bruno JF, Olden JD, Wernberg T, Silliman BR. 2014. Impacts of marine invaders on biodiversity depend on trophic position and functional similarity. Marine Ecology Progress Series 495: $39-47$.

Verlaque M, Ruitton S, Boudouresque CF. 2005. List of invasive or potentially invasive exotic macroalgae in Europe. 5th PCRD European Program 'ALIENS' Algal Introductions To European Shores - Wp 10 Screening Protocol. http://www.uniovi.es/ecologia/aliens/E-aliens. htm.

Vilà M, Basnou C, Pyšek P, Josefsson M, Genovesi P, Gollasch S, Nentwig W, Olenin S, Roques A, Roy D, et al. 2010. How well do we understand the impacts of alien species on ecosystem services? A pan-European, cross-taxa assessment. Frontiers in Ecology and the Environment 8: 135-144.

Williamson M, Fitter A. 1996. The varying success of invaders. Ecology 77: 1661-1666.

With KA. 2004. Assessing the risk of invasive spread in fragmented landscapes. Risk Analysis 24: 803-815.

Zaiko A, Olenin S, Daunys D, Nalepa T. 2007. Vulnerability of benthic habitats to the aquatic invasive species. Biological Invasions 9: 703-714.

Zaiko A, Lehtiniemi M, Narščius A. 2011. Assessment of bioinvasion impacts on a regional scale: a comparative approach. Biological Invasions 13: 1739-1765.

Zenetos A. 2010. Trend in aliens species in the Mediterranean. An answer to Galil, 2010 'Taking stock: inventory of alien species in the Mediterranean Sea'. Biological Invasions 12: 3379-3381.

Zenetos A, Çinar ME, Pancucci-Papadopoulou MA, Harmelin JG, Furnari G. 2005. Annotated list of marine alien species in the Mediterranean with records of the worst invasive species. Mediterranean Marine Science 6: 63-118.

Zenetos A, Gofas S, Verlaque M, Çinar ME, García Raso JE, Bianchi CN, Morri C, Rosso A, Azzurro E, Bilecenoglu M, et al. 2010. Alien species in the Mediterranean Sea by 2010 . A contribution to the application of European Union's Marine Strategy Framework Directive (MSFD). Part I. Spatial distribution. Mediterranean Marine Science 11: 381-493.

Zenetos A, Gofas S, Morri C, Rosso A, Violanti D, García Raso JE, Çinar ME, Almogi-Labin A, Ates AS, Azzurro E, et al. 2012. Alien species in the Mediterranean Sea by 2012. A contribution to the application of European Union's Marine Strategy Framework Directive (MSFD). Part 2. Introduction trends and pathways. Mediterranean Marine Science 13: 328-352. 